\title{
Supramolecular Cluster Catalysis: A Case Study of Benzene Hydrogenation
}

Bruno Therrien, Ludovic Vieille-Petit, Mathieu Tschan, Vladimir B. Romakh, and Georg Süss-Fink*

\section{In memoriam Matthieu Faure}

Abstract: The hydrogenation of benzene to give cyclohexane, catalysed under biphasic conditions by the water-soluble trinuclear arene ruthenium cluster cations $\left[\mathrm{H}_{3} \mathrm{Ru}_{3}\left(\mathrm{C}_{6} \mathrm{H}_{6}\right)\left(\mathrm{C}_{6} \mathrm{Me}_{6}\right)_{2}(\mathrm{O})\right]^{+}(1), \quad\left[\mathrm{H}_{3} \mathrm{Ru}_{3}\left(\mathrm{C}_{6} \mathrm{H}_{5} \mathrm{Me}\right)\right.$ $\left.\left(\mathrm{C}_{6} \mathrm{Me}_{6}\right)_{2}(\mathrm{O})\right]^{+}(\mathbf{2}),\left[\mathrm{H}_{3} \mathrm{Ru}_{3}\left(1,4-\mathrm{MeC}_{6} \mathrm{H}_{4} \mathrm{Pr}^{\prime}\right)\left(\mathrm{C}_{6} \mathrm{Me}_{6}\right)_{2}(\mathrm{O})\right]^{+}(3),\left[\mathrm{H}_{3} \mathrm{Ru}_{3}\left(1,2,4,5-\mathrm{C}_{6} \mathrm{H}_{2} \mathrm{Me}_{4}\right)_{3}(\mathrm{O})\right]^{+}(4),\left[\mathrm{H}_{3} \mathrm{Ru}_{3}\left\{\mathrm{C}_{6} \mathrm{H}_{5}\right.\right.$ $\left.\left.\left(\mathrm{CH}_{2}\right)_{2} \mathrm{OH}\right\}\left(\mathrm{C}_{6} \mathrm{Me}_{6}\right)_{2}(\mathrm{O})\right]^{+}(5)$, and $\left[\mathrm{H}_{3} \mathrm{Ru}_{3}\left\{\mathrm{C}_{6} \mathrm{H}_{5}\left(\mathrm{CH}_{2}\right)_{3} \mathrm{OH}\right\}\left(\mathrm{C}_{6} \mathrm{Me}_{6}\right)_{2}(\mathrm{O})\right]^{+}(6)$, is believed to occur within the hydrophobic pocket spanned by the three arene ligands of the trinuclear cluster, thus forming a supramolecular catalyst-substrate host-guest complex. This paper is a short overview of our research efforts directed to a new catalytic concept for which we coined the term 'supramolecular cluster catalysis'.

Keywords: Arene hydrogenation · Biphasic catalysis · Cluster catalysis · Host-guest complexes · Hydrophobic forces - Intermolecular interactions - Molecular recognition · Second sphere coordination . Supramolecular effects

\section{Introduction}

Organometallic catalysis is generally supposed to proceed through a catalytic cycle that involves the coordination of the substrate, either by ligand substitution or by oxidative addition, transformation of the coordinated substrate, and the liberation of the product, either by decoordination or by reductive elimination (Scheme 1) [1]. Classical examples which have been studied in great detail are the hydrogenation of olefins with Wilkinson's catalyst [2] and the carbonylation of methanol with rhodium iodide (Monsanto Process) [3]. The complete characterisation of the intermediates of the
${ }^{*}$ Correspondence: Prof. G. Süss-Fink Institut de Chimie

Université de Neuchâte

Case postale 2

$\mathrm{CH}-2007$ Neuchâtel

Tel.: +41327182405

Fax: +4132718 2511

E-Mail: georg.suess-fink@unine.ch

www.unine.ch/chim latter process and the proposal of a well-established catalytic cycle represents one of the triumphs of organometallic chemistry [4]. In all these reactions, the elementary steps of the catalytic process are believed to occur within the first coordination sphere of the organometallic catalyst [5].

Only recently catalytic mechanisms without coordination of the substrate to the metal centre of the catalyst molecule have been considered [6][7], based on accumulating evidence for hydrogen transfer within merely hydrogen-bonded substrate-catalyst complexes in the case of catalytic ketone transfer hydrogenation reactions [8] and for oxygen transfer via direct olefin attack to the oxo ligand of the catalyst in epoxidation reactions [9].

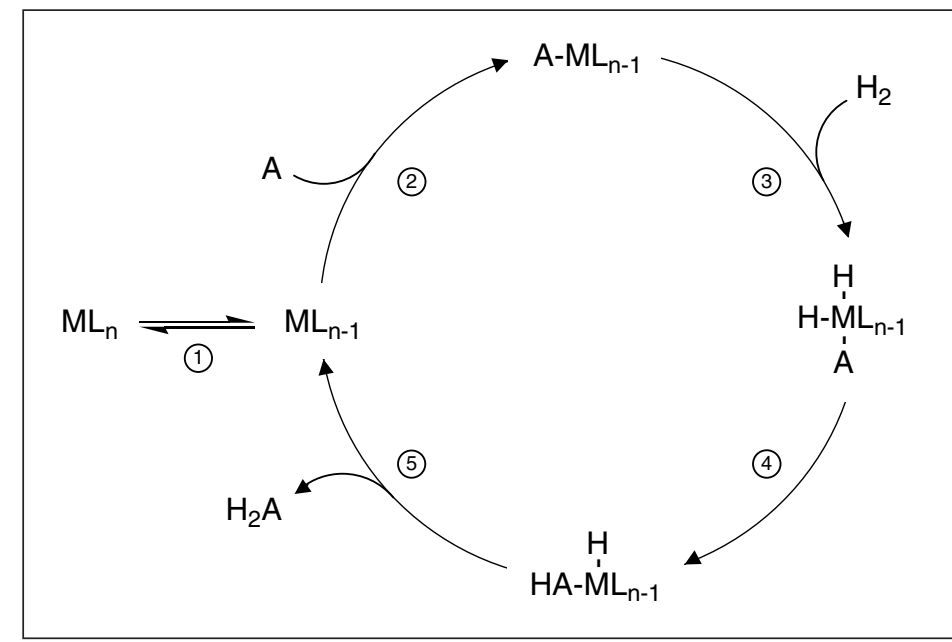

Scheme 1. A conventional catalytic cycle for the mechanistic understanding of a hydrogenation reaction with an organometallic catalyst $(A=$ substrate, $M=$ metal, $L=$ ligand), the elementary steps being: 1) dissociation of a ligand, 2) coordination of the substrate, 3) oxidative addition of hydrogen, 4) migratory rearrangement of the ligands, and 5) reductive elimination of the product 


\section{Hydrogenation of Benzene}

The hydrogenation of benzene to give cyclohexane is an industrial process which is carried out on a millions of tons per year scale; cyclohexane being the basic product for the production of nylon via adipic acid. The industrial catalysts for benzene hydrogenation are heterogeneous catalysts of the Raney nickel or nickel on alox type, which work at high temperature with gas-phase benzene [10]. Following Sabatier's original discovery of benzene hydrogenation catalysed by finely divided nickel in 1901 [11], there has been an enormous amount of work in this area, but this reaction remained predominantly a field of heterogeneous catalysis [12]. Most organometallic complexes known to catalyse the homogeneous hydrogenation of olefins, ketones or acetylenes fail in the case of benzene or other aromatics; the first example of a homogeneous benzene hydrogenation catalyst being $\left(\mathrm{C}_{3} \mathrm{H}_{5}\right) \mathrm{Co}\left[\mathrm{P}(\mathrm{OMe})_{3}\right]_{3}$ reported in 1974 by Muetterties [13]. Other examples include $\left(\mathrm{C}_{6} \mathrm{Me}_{6}\right)_{2} \mathrm{Ru}[14], \mathrm{H}_{2} \mathrm{Ru}_{2}\left(\mathrm{C}_{6} \mathrm{Me}_{6}\right)_{2} \mathrm{Cl}$ [15], $\mathrm{H}_{2} \mathrm{Ru}\left(\mathrm{H}_{2}\right)_{2}\left(\mathrm{Pcy}_{3}\right)_{2} \quad[16], \quad\left[\mathrm{H}_{4} \mathrm{Ru}_{4}\right.$ $\left.\left(\mathrm{C}_{6} \mathrm{H}_{6}\right)_{4}\right] \mathrm{Cl}_{2}$ in water [17] or ionic liquids [18], $\mathrm{Ru}_{2}\left(\mathrm{C}_{6} \mathrm{H}_{6}\right)_{2} \mathrm{Cl}_{2}$ [19], $\mathrm{Rh}_{2}\left(\mathrm{C}_{5} \mathrm{Me}_{5}\right)_{2} \mathrm{Cl}_{2}$ in combination with $\mathrm{NEt}_{3}$ [20]. The most significant development in the field of homogeneous benzene hydrogenation resulted in the Dimersol process by the Institut Français du Pétrole, based on nickel or cobalt alkoxides, acetylacetonates or carboxylates and trialkylaluminium activators [21], which appears to be a viable homogeneous alternative to the heterogeneous technology of industrial benzene hydrogenation [22]. A new generation of homogeneous arene hydrogenation catalysts on the basis of niobium and tantalum hydride derivatives has been published by Rothwell, e.g. $\mathrm{Nb}\left(\mathrm{OC}_{6} \mathrm{HPh}_{4}-2,3,5,6\right)_{2} \mathrm{Cl}_{3}$ in combination with BuLi [23].

$$
\mathrm{C}_{6} \mathrm{H}_{6}+3 \mathrm{H}_{2} \rightarrow \mathrm{C}_{6} \mathrm{H}_{12}
$$

For some organometallic benzene hydrogenation catalysts the true nature of the catalytic species remained for a long time a debatable point ("is it homogeneous or heterogeneous catalysis?') [24]. In the case of the putative homogeneous $\left[\left(\mathrm{C}_{8} \mathrm{H}_{17}\right)_{3} \mathrm{NMe}\right]$ $\left[\mathrm{RhCl}_{4}\right]$ ion pair catalyst [25], Finke and coworkers were able to demonstrate in a pioneering paper that rhodium(O) nanoclusters are the true catalysts ('soluble heterogeneous catalysts') [26]. On the other hand, rhodium colloids obtained from a mixture of $\left[\left(\mathrm{C}_{\mathrm{n}} \mathrm{H}_{2 \mathrm{n}+1}\right) \mathrm{NMe}_{2}\left(\mathrm{CH}_{2} \mathrm{CH}_{2} \mathrm{OH}\right)\right] \mathrm{Br}$ with rhodium powder in water give a reusable suspension for the catalytic hydrogenation of benzene [27].

\section{Supramolecular Cluster Catalysis}

In 1999 we discovered that the cluster cation $\left[\mathrm{H}_{3} \mathrm{Ru}_{3}\left(\mathrm{C}_{6} \mathrm{H}_{6}\right)\left(\mathrm{C}_{6} \mathrm{Me}_{6}\right)_{2}(\mathrm{O})\right]^{+}$(1), employed as the water-soluble tetrafluoroborate salt, efficiently catalyses the hydrobiphasic conditions [28]. From mass spectroscopic measurements and from molecular modelling studies, it can be concluded that the substrate molecule is incorporated in the hydrophobic pocket spanned by the three arene ligands in $\mathbf{1}$ (Fig. 1), suggesting the catalytic reaction to occur within this host-guest complex without prior coordination of the substrate ('supramolecular cluster catalysis') [29].

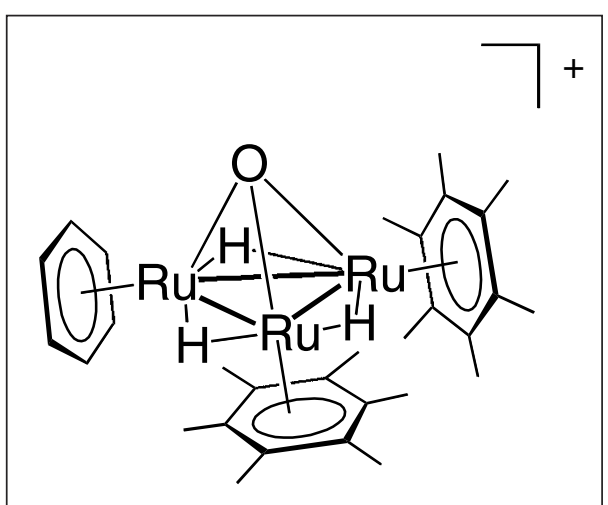

Fig. 1. Molecular structure of cation 1, the three arene ligands forming a hydrophobic pocket underneath the $\mathrm{Ru}_{3}$ plane

The catalyst molecule $\mathbf{1}$ can accommodate the substrate molecule benzene in its arene ligands and place it in a perfect position underneath the $\mathrm{Ru}_{3}$ face opposite to the oxo cap of the cluster. This may be possible as, under biphasic conditions, the hydrophobic substrate tries to escape from the aqueous medium. In the resulting supramolecular catalyst-substrate host-guest complex, the substrate molecule is not cogenation of benzene to cyclohexane under hydrophobic pocket formed by the three

ordinated to ruthenium but interacts with the $\mathrm{Ru}_{3}$ surface only through weak intermolecular interactions. The catalytic hydrogenation is believed to occur within this supramolecular host-guest complex in a three-step mechanism (Scheme 2): Transfer of two hydrogen atoms from the cluster molecule to the substrate within the clusterbenzene complex leads to a cluster-cyclohexadiene complex, in which the unsaturated cluster $\left[\mathrm{HRu}_{3}\left(\mathrm{C}_{6} \mathrm{H}_{6}\right)\left(\mathrm{C}_{6} \mathrm{Me}_{6}\right)_{2}(\mathrm{O})\right]^{+}$ would react with molecular hydrogen to regenerate $\left[\mathrm{H}_{3} \mathrm{Ru}_{3}\left(\mathrm{C}_{6} \mathrm{H}_{6}\right)\left(\mathrm{C}_{6} \mathrm{Me}_{6}\right)_{2}(\mathrm{O})\right]^{+}(\mathbf{1})$, capable of transferring two hydrogen atoms to the cyclohexadiene molecule. In the resulting cluster-cyclohexene complex, the unsaturated cluster $\left[\mathrm{HRu}_{3}\left(\mathrm{C}_{6} \mathrm{H}_{6}\right)\right.$ $\left.\left(\mathrm{C}_{6} \mathrm{Me}_{6}\right)_{2}(\mathrm{O})\right]^{+}$would again react with $\mathrm{H}_{2}$ to regenerate 1 , which would again transfer two hydrogen atoms to the substrate. The cyclohexane formed would leave the hydrophobic pocket, while $\mathbf{1}$ is regenerated with molecular hydrogen. At the end of the catalytic reaction, $\mathbf{1}$ is recovered unchanged as the tetrafluoroborate salt.

No arene ligand substitution is observed during the catalytic reaction: If the catalytic hydrogenation of benzene is carried out with hexadeuterobenzene as the substrate (catalyst/substrate ratio $1: 1000,110{ }^{\circ} \mathrm{C}$, $60 \mathrm{bar}$ ), the reaction yields as expected 1,2,3,4,5,6-hexadeuterocyclohexane, while cluster 1 still contains one $\mathrm{C}_{6} \mathrm{H}_{6}$ and two $\mathrm{C}_{6} \mathrm{Me}_{6}$ ligands (and no coordinated $\mathrm{C}_{6} \mathrm{D}_{6}$ ) after the catalytic reaction. This observation rules out an $\eta^{6}$-coordination of the substrate to a metal centre in this catalytic reaction, suggesting only supramolecular effects for the interaction between the catalyst and the substrate. This hypothesis is further supported by the striking substrate selectivity of the cluster catalyst: Only benzene and moderately hindered benzene derivatives are efficiently hydrogenated to give the corresponding cyclohexanes; 1,2,4,5-tetramethyl- and hexamethylben-

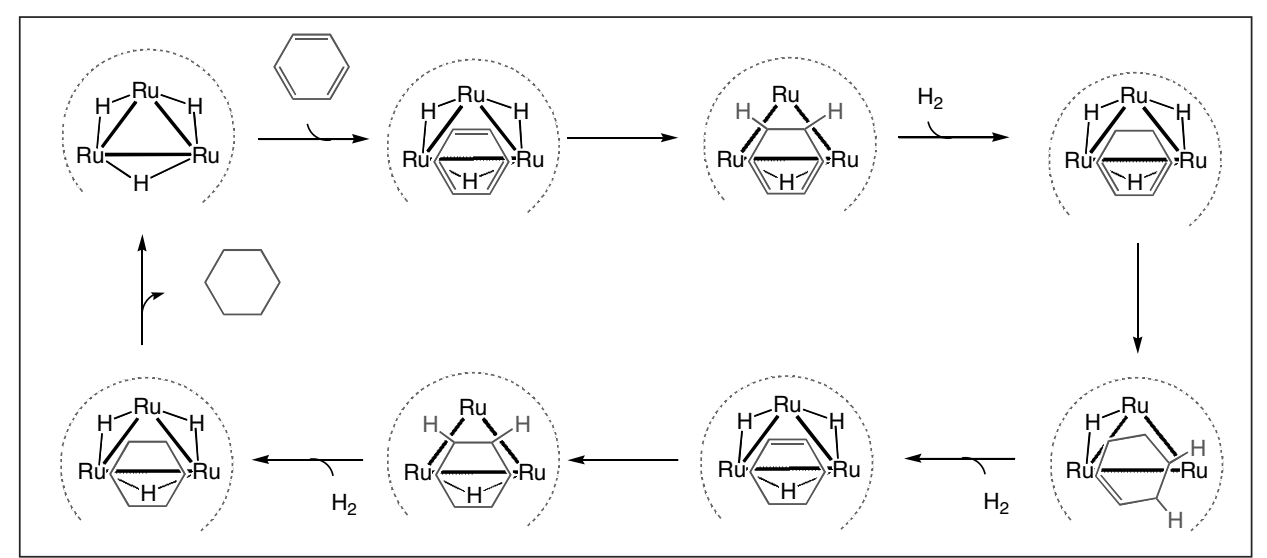

Scheme 2. Proposed mechanism for the stepwise catalytic hydrogenation of benzene to cyclohexane within the hydrophobic pocket (dashed line) spanned by the three arene ligands of the intact trinuclear cluster cations 1-6 (arene ligands and oxo cap omitted for clarity) 
zene are not hydrogenated at all by $\mathbf{1}$ under the same conditions. Obviously the cluster cation recognises benzene and simple benzene derivatives; highly substituted benzene derivatives are too bulky to fit into its hydrophobic pocket.

The morphology of the hydrophobic pocket can be adapted by modifying the arene ligands in the trinuclear cluster cation, the limitation being the stability of the triruthenium framework: A cluster cation analogous to $\mathbf{1}$ containing three hexamethylbenzene ligands cannot be synthesised, as three $\mathrm{C}_{6} \mathrm{Me}_{6}$ ligands are too bulky for a trinuclear cluster, and the corresponding cluster cation with three $\mathrm{C}_{6} \mathrm{H}_{6}$ ligands is unstable under hydrogenation conditions [30]. However, the cluster cations containing two hexamethylbenzene ligands and another arene ligand, $\left[\mathrm{H}_{3} \mathrm{Ru}_{3}\right.$ $\left.\left(\mathrm{C}_{6} \mathrm{H}_{5} \mathrm{Me}\right)\left(\mathrm{C}_{6} \mathrm{Me}_{6}\right)_{2}(\mathrm{O})\right]^{+}(\mathbf{2}),\left[\mathrm{H}_{3} \mathrm{Ru}_{3}(1,4-\right.$ $\left.\left.\mathrm{MeC}_{6} \mathrm{H}_{4} \mathrm{Pr}^{i}\right)\left(\mathrm{C}_{6} \mathrm{Me}_{6}\right)(\mathrm{O})\right]^{+}(\mathbf{3}), \quad\left[\mathrm{H}_{3} \mathrm{Ru}_{3}\right.$ $\left.\left\{\mathrm{C}_{6} \mathrm{H}_{5}\left(\mathrm{CH}_{2}\right)_{2} \mathrm{OH}\right\}\left(\mathrm{C}_{6} \mathrm{Me}_{6}\right)_{2}(\mathrm{O})\right]^{+}(\mathbf{5})$, and $\left[\mathrm{H}_{3} \mathrm{Ru}_{3}\left\{\mathrm{C}_{6} \mathrm{H}_{5}\left(\mathrm{CH}_{2}\right)_{3} \mathrm{OH}\right\}\left(\mathrm{C}_{6} \mathrm{Me}_{6}\right)_{2}(\mathrm{O})\right]^{+}$ (6), have been prepared by analogy from the dinuclear precursor $\left[\mathrm{H}_{3} \mathrm{Ru}_{2}\left(\mathrm{C}_{6} \mathrm{Me}_{6}\right)_{2}\right]^{+}$ and the corresponding mononuclear arene ruthenium triaqua complex [31], while the only symmetrical complex $\left[\mathrm{H}_{3} \mathrm{Ru}_{3}(1,2,4,5\right.$ $\left.\left.\mathrm{C}_{6} \mathrm{H}_{2} \mathrm{Me}_{4}\right)_{3}(\mathrm{O})\right]^{+}(4)$ containing three durene ligands is accessible from (durene)ruthenium dichloride dimer and hydrogen in aqueous solution [32]. All these cationic complexes 2-6 catalyse the hydrogenation of benzene under biphasic conditions in the same way as $\mathbf{1}$ (Table), the most active catalyst being the toluene derivative $\mathbf{2}$ and the least active one the para-cymene derivative 3. Presumably, there is a fine balance between steric and electronic effects: Toluene as the third arene ligand forms a hydrophobic pocket similar to that formed by benzene but, as it is more electron-rich, the activity of $\mathbf{2}$ is slightly higher than that of $\mathbf{1}$. However, with the bulkier para-cymene ligand the hydrophobic pocket seems to be

Fig. 2. Molecular structure of cations 5 at $25 \%$ probability level, $\mathrm{H}$ atoms and $\mathrm{PF}_{6}$ omitted for clarity

Table 1. Hydrogenation of benzene to give cyclohexane under biphasic conditions ${ }^{a}$

\begin{tabular}{|c|c|c|c|c|}
\hline Catalyst & Cation & Yield [\%] & TONC & TOF $\left[h^{-1}\right]^{d}$ \\
\hline $\begin{array}{l}{\left[\mathrm{H}_{3} \mathrm{Ru}_{3}\left(\mathrm{C}_{6} \mathrm{H}_{6}\right)\left(\mathrm{C}_{6} \mathrm{Me}_{6}\right)_{2}(\mathrm{O})\right]\left[\mathrm{BF}_{4}\right]} \\
{\left[\mathrm{H}_{3} \mathrm{Ru}_{3}\left(\mathrm{C}_{6} \mathrm{H}_{5} \mathrm{Me}\right)\left(\mathrm{C}_{6} \mathrm{Me}_{6}\right)_{2}(\mathrm{O})\right]\left[\mathrm{BF}_{4}\right]} \\
{\left[\mathrm{H}_{3} \mathrm{Ru}_{3}\left(1,4-\mathrm{MeC}_{6} \mathrm{H}_{4} \mathrm{Pr}^{\prime}\right)\left(\mathrm{C}_{6} \mathrm{Me}_{6}\right)_{2}(\mathrm{O})\right]\left[\mathrm{BF}_{4}\right]} \\
{\left[\mathrm{H}_{3} \mathrm{Ru}_{3}\left(1,2,4,5-\mathrm{C}_{6} \mathrm{H}_{2} \mathrm{Me}_{4}\right)_{3}(\mathrm{O})\right]\left[\mathrm{BF}_{4}\right]} \\
{\left[\mathrm{H}_{3} \mathrm{Ru}_{3}\left\{\mathrm{C}_{6} \mathrm{H}_{5}\left(\mathrm{CH}_{2}\right)_{2} \mathrm{OH}\right\}\left(\mathrm{C}_{6} \mathrm{Me}_{6}\right)_{2}(\mathrm{O})\right]\left[\mathrm{BF}_{4}\right]} \\
{\left[\mathrm{H}_{3} \mathrm{Ru}_{3}\left\{\mathrm{C}_{6} \mathrm{H}_{5}\left(\mathrm{CH}_{2}\right)_{3} \mathrm{OH}\right\}\left(\mathrm{C}_{6} \mathrm{Me}_{6}\right)_{2}(\mathrm{O})\right]\left[\mathrm{BF}_{4}\right]}\end{array}$ & $\begin{array}{l}1 \\
2 \\
3 \\
4 \\
5 \\
6\end{array}$ & $\begin{array}{l}76 \\
83 \\
14 \\
15 \\
56 \\
50\end{array}$ & $\begin{array}{l}760 \\
828 \\
140 \\
150 \\
560 \\
500\end{array}$ & $\begin{array}{r}190 \\
207 \\
35 \\
37 \\
140 \\
125\end{array}$ \\
\hline \multicolumn{5}{|c|}{$\begin{array}{l}\text { a Conditions: } \mathrm{H}_{2} \mathrm{O} 10 \mathrm{ml} \text {, catalyst } 0.01 \mathrm{mmol} \text {, benzene } 10 \mathrm{mmol} \text {, hydrogen pressure } 60 \mathrm{~b} \\
\text { temperature } 110^{\circ} \mathrm{C} \text {, stirring frequency } 900 \mathrm{~min}^{-1} \\
\text { b Determined by gas chromatography } \\
\text { c Catalytic Turnover Number: mol product formed per mol catalyst } \\
\text { d (Mean) Catalytic Turnover Frequency: mol product formed per mol catalyst and per } \\
\text { time unit }\end{array}$} \\
\hline
\end{tabular}

less accessible, for this reason $\mathbf{3}$ is the least active catalyst despite its electron-rich character.

\section{Isolation of the Supramolecular Catalyst-Substrate Host-Guest Complexes}

In the case of the cluster cations $\mathbf{5}$ and $\mathbf{6}$, containing a $\left(\mathrm{CH}_{2}\right)_{\mathrm{n}} \mathrm{OH}(\mathrm{n}=2,3)$ side-arm at the benzene ligand, we were able to isolate the catalyst-substrate host-guest complexes $\left[\mathrm{C}_{6} \mathrm{H}_{6} \subset \mathbf{5}\right]\left[\mathrm{PF}_{6}\right]$ and $\left[\mathrm{C}_{6} \mathrm{H}_{6} \subset \mathbf{6}\right]\left[\mathrm{BF}_{4}\right]$ and to characterise these supramolecular intermediates postulated by single-crystal $\mathrm{X}$-ray structure analysis [31]. A structural comparison of $\mathbf{5}$ and $\left[\mathrm{C}_{6} \mathrm{H}_{6} \subset \mathbf{5}\right]^{+}$shows almost identical geometrical parameters; differences appear only at the periphery (Fig. 2)

In the two catalyst-substrate complexes isolated, the substrate guest is received by the catalyst host in an inclined fashion inside the hydrophobic pocket: $\operatorname{In}\left[\mathrm{C}_{6} \mathrm{H}_{6} \subset \mathbf{5}\right]^{+}$, the angle formed by the $\mathrm{C}_{6}$ plane and the $\mathrm{Ru}_{3}$ plane is $66.78(7)^{\circ}$, while it is $88.63(9)^{\circ}$ in $\left[\mathrm{C}_{6} \mathrm{H}_{6} \subset 6\right]^{+}$, the shortest distances between the metal-bound hydrogen atoms and the closest carbon atoms of the benzene guest molecule being 3.49 and $3.69 \AA$ in $\left[\mathrm{C}_{6} \mathrm{H}_{6} \subset 5\right]^{+}$, and 3.26 and $3.77 \AA$ in $\left[\mathrm{C}_{6} \mathrm{H}_{6} \subset \mathbf{6}\right]^{+}$(Fig. 3).

The direct observation of the catalystsubstrate host-guest complexes was the missing link in the concept of supramolecular cluster catalysis. The isolation and the $\mathrm{X}$-ray crystallographic characterisation of $\left[\mathrm{C}_{6} \mathrm{H}_{6} \subset 5\right]\left[\mathrm{PF}_{6}\right]$ and $\left[\mathrm{C}_{6} \mathrm{H}_{6} \subset \mathbf{6}\right]\left[\mathrm{BF}_{4}\right]$ now allow a deeper mechanistic insight into this catalytic reaction.

\section{Conclusions}

The catalytic systems described herein lie at the interface between homogeneous, heterogeneous and enzymatic catalysis (Fig. 4): As in homogeneous catalysis, the catalysts are soluble molecular species, as in heterogeneous catalysis, the reaction takes place in a two-phase system, and as in enzymatic catalysis, there is molecular recognition of the substrate by the catalyst.

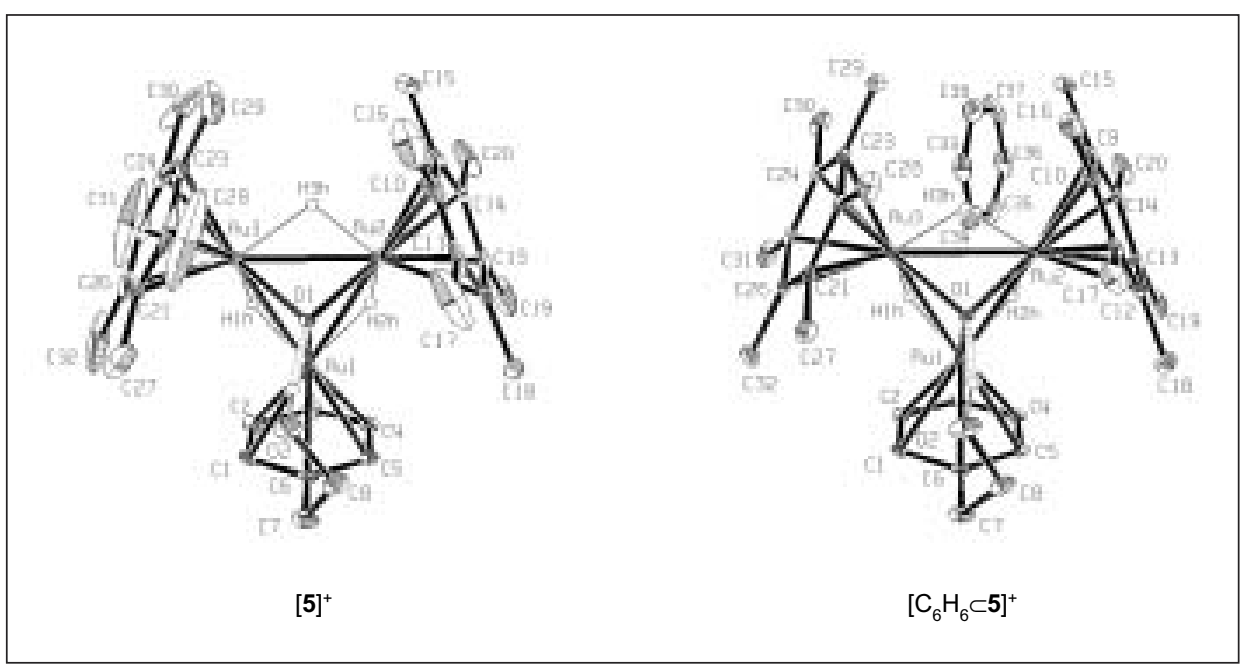



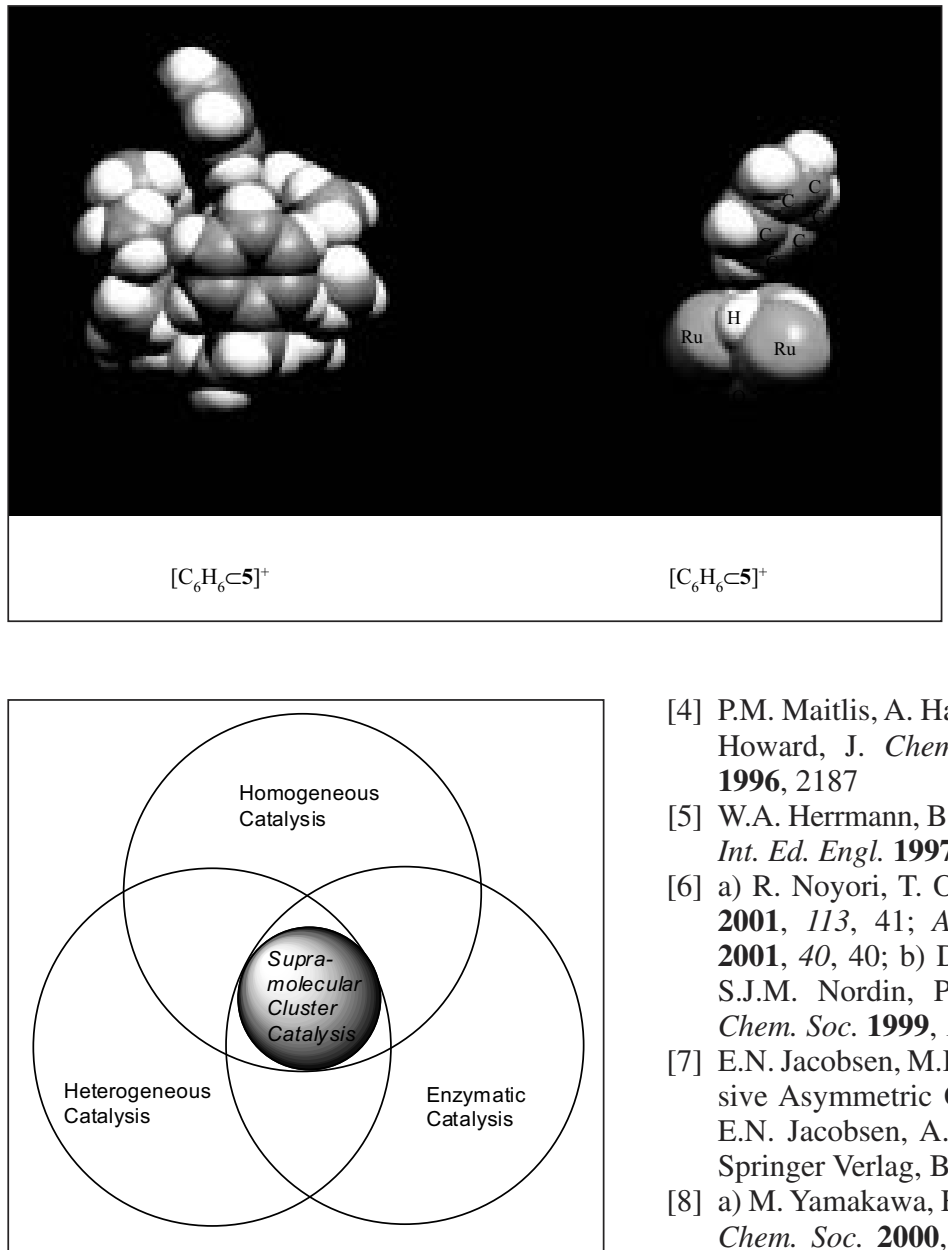

Fig. 4. Supramolecular cluster catalysis at the interface between homogeneous, heterogeneous and enzymatic catalysis

Furthermore, these catalysts are devoid of expensive ligands: They can be formally regarded as solubilised ruthenium ions, the ligands provided either by the solvents (arene or water-derived anions) or the gas $\left(\mathrm{H}_{2}\right)$.

\section{Acknowledgements}

The authors are grateful to the Fonds $\mathrm{Na}$ tional Suisse de la Recherche Scientifique for financial support. A generous loan of ruthenium chloride hydrate from the Johnson Matthey Technology Centre is gratefully acknowledged.

Received: July 14, 2003

[1] a) S. Bhaduri, D. Mukesh, 'Homogeneous Catalysis', Wiley-Interscience, New York, 2000; b) B. Cornils, W.A. Herrmann, 'Applied Homogeneous Catalysis with Organometallic Compounds', VCH, Weinheim, 1996; c) G.W. Parshall, S.D. Ittel, 'Homogeneous Catalysis', Wiley-Interscience, New York, 1992

[2] B.R. James, Adv. Organomet. Chem. 1979, 17,319 .

[3] D. Forster, Adv. Organomet. Chem. 1979, $17,255$.
Fig. 3. Space filling representation of the host-quest complexes $\left[\mathrm{C}_{6} \mathrm{H}_{6} \subset 5\right]^{+}$, based on the X-ray data, showing the benzene host (top) penetrating the hydrophobic pocket (left), the arene ligands being omitted for clarity (right)
[4] P.M. Maitlis, A. Haynes, G.J. Sunley, M.J. Howard, J. Chem. Soc. Dalton Trans. 1996, 2187

[5] W.A. Herrmann, B. Cornils, Angew. Chem. Int. Ed. Engl. 1997, 36, 1048.

[6] a) R. Noyori, T. Ohkuma, Angew. Chem. 2001, 113, 41; Angew. Chem. Int. Ed. 2001, 40, 40; b) D.A. Alonso, P. Brandt, S.J.M. Nordin, P.G. Andersen, J. Am. Chem. Soc. 1999, 121, 9580

[7] E.N. Jacobsen, M.H. Wu, in: 'Comprehensive Asymmetric Catalysis', Vol. II, eds: E.N. Jacobsen, A. Pfaltz, H. Yamamoto, Springer Verlag, Berlin, 1999, p. 650.

[8] a) M. Yamakawa, H. Ito, R. Noyori, J. Am. Chem. Soc. 2000, 122, 1466; b) K. Abdur Rashid, A.J. Lough, R.H. Morris, Organometallics 2000, 19, 2655; c) D.G.I. Petra, J.N.H. Reek, J.-W. Handgraaf, E.J. Meijer, P. Dierkes, P.C.J. Kamer, J. Brussee, H.E. Schoemaker, P.W.N.M. van Leeuwen, Chem. Eur. J. 2000, 6, 2818

[9] M. Palucki, N.S. Finney, P.J. Pospisil, M.L. Güler, T. Ishida, E.N. Jacobsen, J. Am. Chem. Soc. 1998, 120, 948.

[10] K. Weissermel, H.-J. Arpe, 'Industrial Organic Chemistry', 2nd edn., VCH, New York, 1993, 343.

[11] a) P. Sabatier, J.-B. Sendersens, Comt. Rend. 1901, 132, 210; b) P. Sabatier, Ind. Eng. Chem. 1926, 18, 1004.

[12] A literature search (SciFinder connecting to CAS) of benzene hydrogenation reveals 1498 references (April 2003), including only 54 references for homogeneous benzene hydrogenation.

[13] a) E.L. Muetterties, F.J. Hirsekorn, J. Am Chem. Soc. 1974, 96, 4063; b) F.J. Hirsekorn, M.C. Rakowski, E.L. Muetterties, $J$. Am. Chem. Soc. 1975, 97, 237; c) F.J. Hirsekorn, M.C. Rakowski, E.L. Muetterties, W.D. Larson, V.J. Basus, F.A.L. Anet, J. Am. Chem. Soc. 1975, 97, 1266; d) M.C. Rakowski, F.J. Hirsekorn, L.S. Stuhl, E.L. Muetterties, Inorg. Chem. 1976, 15, 2379; e) L.S. Stuhl, M. Rakowski DuBois, F.J. Hirsekorn, J.R. Bleeke, A.E. Stevens, E.L. Muetterties, J. Am. Chem. Soc. 1978, 100, 2405.

[14] J.W. Johnson, E.L. Muetterties, J. Am Chem. Soc. 1977, 99, 7395.

[15] M.A. Bennett, T.-N. Huang, T.W. Turney, J. Chem. Soc. Chem. Commun. 1979, 312.
[16] A.F. Borowski, S. Sabo-Etienne, B. Chaudret, J. Mol. Catal. A: Chemical 2001, $174,69$.

[17] L. Plasseraud, G. Süss-Fink, J. Organometal. Chem. 1997, 539, 163.

[18] P.J. Dyson, D.J. Ellis, D.G. Parker, T. Welton, J. Chem. Soc. Chem. Commun. 1999, 25.

[19] E. Garcia Fidalgo, L. Plasseraud, G. SüssFink, J. Mol. Catal. A: Chemical 1998, $132,5$.

[20] M.A. Bennett, T.-N. Huang, T.W. Turney, J. Chem. Soc., Chem. Comm. 1979, 312.

[21] D. Durand, G. Hillion, C. Lassau, L. Sajus, US Patent 4,271,323 (1981).

[22] H. Brunner, 'Hydrogenation', in [1b], p. 216.

[23] a) I.P. Rothwell, J. Chem. Soc. Chem Commun. 1997, 1331; b) V.M. Visciglio, J.R. Clark, M.T. Nguyen, D.R. Mulford, P.E. Fanwick, I.P. Rothwell, J. Am. Chem Soc. 1997, 119, 3490

[24] Y. Lin, R.G. Finke, Inorg. Chem. 1994, 33, 4891.

[25] K.R. Januszklewicz, H. Alper, Organometallics 1983, 2, 1055; b) J. Blum, J. Amer, K P.C. Vollhardt, H. Schwarz, G. Hohne, J. Org. Chem. 1987, 52, 2804.

[26] K.S. Weddle, J.D. Aiken III, R.G. Finke, J. Am. Chem. Soc. 1998, 120, 5653.

[27] a) J. Schulz, A. Roucoux, H. Patin, $J$. Chem. Soc., Chem. Commun. 1999, 535 b) J. Schulz, A. Roucoux, H. Patin, Chem. Eur. J. 2000, 6, 618

[28] M. Faure, M. Jahncke, A. Neels, H. Stœckli-Evans, G. Süss-Fink, Polyhedron 1999, 18, 2679.

[29] G. Süss-Fink, M. Faure, T.R. Ward, Angew. Chem. 2002, 114, 105; Angew. Chem. Int. Ed. 2002, 41, 99.

[30] E. Garcia Fidalgo, L. Plasseraud, G. SüssFink, J. Mol Catal. A 1998, 132, 5 .

[31] L. Vieille-Petit, B. Therrien, G. Süss-Fink, T.R. Ward, J. Organomet. Chem., in press.

[32] G. Meister, G. Rheinwald, H. StoeckliEvans, G. Süss-Fink, J. Chem. Soc. Dalton Trans. 1994, 3215. 